\title{
ANALISIS PENGARUH KEBIJAKAN DIVIDEN DAN LEVERAGE TERHADAP NILAI PERUSAHAAN DENGAN AGENCY COST SEBAGAI VARIABEL INTERVENING PADA EMITEN MANUFAKTUR SEKTOR INDUSTRI BARANG KONSUMSI YANG TERDAFTAR DI BURSA EFEK INDONESIA
}

\author{
Iwan Kusuma Negara*)
}

\begin{abstract}
This research examines the influence of dividend policy and leverage on firm value with agency cost as an intervening variable in manufacturing companies in the consumer goods industry sector listed at Indonesia Stock Exchange in the period of 2012-2016. The type of research used is associative research. Anumber of populationin this research are 42 firms. Sampling technique used purposive sampling, so selected 14 firms as research sample.Research variables consist of Dividend policy proxied byDividend Per Share (DPS), Leverage proxied byDebt to Equity Ratio (DER), Agency cost proxied by effectiveness, and firm value proxied byPrice to Book Value (PBV).Data analysis uses simple regression, path analysis, and Sobel test.The research resultindicates that dividend policy has a significant negative effect on Agency cost. Leverage has a negative significant effect on Agency cost. Dividend policy has a significant positive effect on firm value. Leverage has a significant positive effect on firm value. Agency cost has a significant negative effect on firm value. The test results using path analysis and sobel test show that Agency cost is able to mediate the influence of dividend policy on firm value. Nevertheless, Agency cost is unable to mediate the effect of leverage on firm value.
\end{abstract}

Keywords : Firm value, Dividend policy, Leverage, Agency cost, Intervening variable

\section{Pendahuluan}

Tujuan utama suatu perusahaan adalah meningkatkan kemakmuran para pemegang saham(Wealth of the stockholders) yang diterjemahkan ke dalam memaksimalkan harga saham perusahaan. Harga saham yang maksimal (tinggi) akan membuat nilai perusahaan semakin tinggi (Hermuningsih, 2013). Nilai perusahaan(Firm value) yang tinggi menjadi keinginan para pemilik perusahaan, karena dengan nilai perusahaan yang tinggi menunjukkan kemakmuran para pemegang saham juga tinggi.

Nilai perusahaan sangat penting karena mencerminkan kinerja perusahaan yang dapat mempengaruhi persepsi investor terhadap keberhasilan atau kinerja perusahaan, yang sering dikaitkan dengan harga saham.Harga saham di pasar modal terbentuk berdasarkan kesepakatan antara permintaan dan penawaran investor, sehingga harga saham merupakan fair price yang dapat dijadikan sebagai proksi nilai perusahaan (Hasnawati, 2005).

Industri Barang Konsumsi merupakan industri yang cukup pesat perkembangannya dan sangat penting peranannya dalam perekonomian Indonesia.Hal ini menunjukkan di tengah situasi perekonomian global yang sedang tidak menentu ini saham di sektor barang konsumsi tersebut mampu bertahan. Banyak investor yang lebih tertarik menginvestasikan dananya pada perusahaan industri barang konsumsi ini karena kinerjanya meningkat setiap tahun dan merupakan salah satu sektor yang menawarkan saham-saham yang memiliki prospek yang menguntungkan.Perusahaan yang tergabung ke dalam industri barang konsumsi memiliki tingkat persaingan yang tinggi, sehingga menuntut kinerja perusahaan yang selalu prima agar unggul dalam persaingan.Kondisi ini turut mempengaruhi pergerakan harga saham emiten dalam sektor industri barang konsumsi, ketertarikan investor terhadap saham perusahaan tersebut tercermin dari fluktuasi harga

\footnotetext{
*) Fakultas Ekonomi dan Bisnis Unram, Email : iwanegara@yahoo.com
} 
sahamnya di BEI.Perkembangan harga saham pada suatu perusahaan mencerminkan nilai saham perusahaan tersebut, sehingga kemakmuran pemegang saham dicerminkan dari harga pasar sahamnya.Harga saham merupakan harga yang terjadi di pasar bursa pada saat tertentu dan harga saham tersebut ditentukan oleh pelaku pasar (Jogiyanto, 2013; Tansil, 2015).

Nilai perusahaan merupakan perbandingan antara harga pasar saham (Stock market price) perusahaan dengan nilai buku per lembar saham (Book value pershare), atau yang lazim disebut Price to Book Value (PBV). Nilai buku yaitu nilai saham menurut pembukuan perusahaan emiten, atau perbandingan antara total ekuitas dengan jumlah saham beredar (Tansil, 2015). Nilai perusahaan merupakan salah satu ukuran keberhasilan atas pelaksanaan fungsi-fungsi keuangan.Nilai perusahaan dapat dijadikan sebagai indikasi keberhasilan perusahaan dalam mencapai tujuan yang ditetapkan.Perusahaan yang berhasil mempunyai rasio Price to book value lebih besar dari satu (PBV > 1), yang berarti pasar percaya bahwa nilai pasar perusahaan tersebut lebih besar dari nilai buku saham (Jogiyanto, 2008; Tansil 2015). Berdasarkan nilai PBV yang dimiliki oleh setiap perusahaan, maka para investor juga dapat memprediksi saham-saham perusahaan mana yang undervalued (murah) dan overvalued (mahal), sehingga dapat menentukan strategi investasi yang sesuai dengan harapan untuk memperoleh dividen yang tinggi (Dwiaji, 2011).

Nilai perusahaan dapat ditingkatkan melalui struktur modal dengan proksi Debt to equity ratio (Hermuningsih, 2013).Kebijakan hutang merupakan instrumen yang sensitif terhadap perubahan nilai perusahaan (Hertiana, 2016). Menurut Wijaya et. al (2010) nilai perusahaan (Firm value) dipengaruhi oleh kebijakan dividen. Nilai perusahaan juga dipengaruhi oleh agency cost yang ditimbulkan karena adanya konflik antara agent (manajer) dengan principals (para pemegang saham) (Wang, 2010; Faisal, 2013; Tansil, 2015).Somantri et. al (2016) menyatakan bahwa nilai perusahaan juga dipengaruhi oleh agency cost yang ditimbulkan karena adanya konflik antara agent (manajer) dengan principals (para pemegang saham).

Kebijakan hutang perusahaan dapat dilihat dari rasio leverage. Rasio leverage yaitu rasio yang mengukur sampai seberapa jauh aktiva perusahaan dibiayai dari hutang (Munawir, 2010). Penggunaan hutang akan meningkatkan nilai perusahaan, karena saat kebutuhan hutang naik, dana itu digunakan untuk pembiayaan perusahaan. Semakin tinggi proporsi hutang, semakin tinggi harga saham. Namun pada titik tertentu, hutang yang tinggi akan menurunkan nilai perusahaan. Hasil penelitian Rustendi dan Jimmi (2008) menunjukkan bahwa hutang berpengaruh positif terhadap nilai perusahaan.Hasil penelitian tersebut sejalan (konsisten) dengan temuan Hertiana (2016) yang menyatakan bahwa leverage berpengaruh positif terhadap nilai perusahaan. Hal ini berarti, semakin besar proporsi hutang dalam perusahaan, maka semakin besar pula nilai perusahaan.

Kebijakan dividen(Dividend policy) berkaitan dengan kebijakan perusahaan mengenai seberapa besar dividen tunai yang harus dibagikan kepada para pemegang saham dari laba yang dibukukan.Apabila perusahaan memiliki rasio pembayaran dividen yang relatif stabil dan meningkat setiap tahunnya, maka akan dapat menimbulkan tanggapan yang positif dari para investor, yang dapat meningkatkan harga saham dan meningkatnya harga saham akan meningkatkan nilai perusahaan (Sujoko dan Soebiantoro, 2007; Dwiaji, 2011). Hal ini didukung oleh temuan Wijaya et. al (2010) dan Tansil (2015) yang menyatakan bahwa kebijakan dividen berpengaruh positif terhadap nilai perusahaan.

Agency costs (biaya keagenan) adalah biaya yang berhubungan dengan monitoring atau pengawasan tindakan agent (manajer) untuk menyakinkan bahwa tindakan agent konsisten dengan persetujuan kontrak antara agent, principalsdan kreditur. Permasalahan agent dipicu oleh tingkat kepentingan antara principals dan agent yang berbeda (Kleiman, 2014). Agent cenderung akan menginvestasikan kembali sebagian besar laba yang diperoleh agar perusahaan yang dipimpinnya terus mengalami pertumbuhan yang lebih tinggi. Laba 
perusahaan yang semakin banyak diinvestasikan kembali (reinvestment), maka akan tersisa sedikit laba yang akan dibagikan kepada pemegang saham dalam bentuk dividen tunai. Hal ini sangat bertolak belakang dengan keinginan principals, yang senantiasa menghendaki laba yang dihasilkan perusahaan dapat dibagikan sebagai dividen dalam jumlah yang relatif besar dari tahun ke tahun.

Konflik antara agent dan principals tersebut dapat memperbesar biaya monitoring atau agency cost, dimana besarnya agency cost dapat berdampak pada menurunnya laba dan kecilnya dividen yang dibagikan kepada para pemegang saham. Agency cost yang besar dan dividen yang kecil akan menimbulkan tanggapan yang negatif dari para pemegang saham dan investor di pasar modal, sehingga dapat menurunkan harga saham dan nilai perusahaan.

Pada tabel berikut disajikan data rata-rata Dividend Per Share (DPS), Debt to Equity Ratio (DER), Agency cost, dan Price to Book Value (PBV) perusahaan Industri Barang Konsumsi yang terdaftar di BEI periode 2012-2016.

Tabel 1. Data Rata-Rata Variabel DPS, DER, Agency Cost, dan PBV

Sektor Industri Barang Konsumsi Periode 2012-2016

\begin{tabular}{|l|l|l|l|l|l|}
\hline Variabel & $\mathbf{2 0 1 2}$ & $\mathbf{2 0 1 3}$ & $\mathbf{2 0 1 4}$ & $\mathbf{2 0 1 5}$ & $\mathbf{2 0 1 6}$ \\
\hline DPS (Rp) & 798,66 & $1.678,10$ & 259,58 & 258,18 & 137,48 \\
\hline DER $(x)$ & 0,98 & 2,50 & $-0,33$ & 0,85 & 0,64 \\
\hline AC & 0,67 & 2,33 & 1,67 & 0,98 & 1,01 \\
\hline PBV $(x)$ & 4,19 & 4,95 & 4,74 & 4,83 & 6,23 \\
\hline
\end{tabular}

Sumber : Data Laporan Tahunan (diolah)

Berdasarkan tabel 1 di atas menunjukkan adanya fluktuasi nilai rata-rata DPS, DER, Agency Cost (AC), danPBV pada Sektor Industri Barang Konsumsi selama tahun 2012 sampai dengan 2016. Nilai perusahaan yang diproksikan dengan PBV pada periode 20142016 mengalami peningkatan secara berturut-turut dari 4,74 kali, 4,83 kali sampai dengan peningkatan tertinggi pada tahun 2016 sebesar 6,23 kali. Peningkatan PBV pada tahun 2016 disebabkan oleh meningkatnya harga saham sektor industri barang konsumsi. Peningkatan PBV akan menciptakan persepsi positif bagi investor terhadap nilai perusahaan yang akan berdampak pada keputusan para investor untuk membeli saham. Jika dihubungkan dengan agency cost, nilai perusahaan yang tinggi seharusnya dapat menurunkan agency cost. Pada tabel 1 nampak bahwa peningkatan nilai perusahaan pada tahun 2016 sebesar 1,01 kali diikuti dengan peningkatan agency cost. Hal ini berarti kenaikan nilai perusahaan diikuti dengan kenaikan agency cost. Pada tabel yang sama jugamenunjukkan kenaikan DPS tertinggi terjadi pada tahun 2013 sebesar Rp1.678,10 yang dimana kenaikan DPS tersebut tidak diikuti dengan penurunan agency cost. Dengan demikian, terdapat perbedaan antara fenomena bisnis (data empiris) dengan teori.

Beberapa hasil penelitian terdahulu terkait pengaruh kebijakan dividen,leveragedan Agency costterhadap nilai perusahaan telah banyak dilakukan, namun temuan-temuan dalam penelitian tersebut menunjukkan hasil yang inkonsisten (berbeda) antara peneliti yang satu dengan peneliti yang lainnya.Hasil penelitian yang dilakukan oleh Wijaya et. al (2010), Haryanti (2011), dan Tansil (2015) menyatakan bahwa kebijakan dividen berpengaruh positif terhadap nilai perusahaan. Hasil penelitian tersebut tidak sejalan dengan hasil penelitian Sukirni (2012) yang menyatakan bahwa kebijakan dividen berpengaruh negatif terhadap nilai perusahaan.

Hasil penelitian Putri (2015), Pamungkas (2016) dan Triwahyuni (2016) menyatakan bahwa kebijakan dividen berpengaruh negatif signifikan terhadap Agency cost. Temuan ini berbeda dengan temuan Muttaqien (2010) bahwa kebijakan dividen berpengaruh positif signifikan terhadap Agency cost.

Penelitian yang dilakukan Rustendi dan Jimmi (2008),Haryanti (2011), Hermuningsih (2013), Ambarwati dan Stephanus (2014), Tansil (2015), dan Hertiana (2016) menunjukkan 
bahwa leverage berpengaruh positif terhadap nilai perusahaan. Namun demikian, temuan tersebut berbeda dengan temuan Umi, Gatot dan Ria (2012).

Temuan Haryanti (2011), Tansil (2015), dan Hertiana (2016) menyatakan bahwa agency cost berpengaruh negatif terhadap nilai perusahaan. Temuan tersebut bertolak belakang dengan hasil penelitian Somantriet. al (2016) yang menyatakan bahwa agency cost berpengaruh positif terhadap nilai perusahaan.Beberapa studi empirik sebagaimana dikemukakan di atas menyajikan hasil yang berbeda-beda.Research gap tersebut menjadi alasan peneliti untuk mengkaji lebih dalam tentang variabel-variabel yang mempengaruhi nilai perusahaan (Firm value).

\section{Tujuan Penelitian}

Tujuan dari penelitian ini adalah sebagai berikut :

1. Untuk menganalisis pengaruh kebijakan dividen terhadap Agency cost.

2. Untuk menganalisis pengaruh leverage terhadap Agency cost.

3. Untuk menganalisis pengaruh kebijakan dividen terhadap nilai perusahaan.

4. Untuk menganalisis pengaruh leverage terhadap nilai perusahaan.

5. Untuk menganalisis pengaruh Agency cost terhadap nilai perusahaan.

6. Untuk menganalisis pengaruh kebijakan dividen dan leverage secara tidak langsung terhadap nilai perusahaan.

\section{Landasan Teori}

\subsection{Nilai Perusahaan (Firm Value)}

Nilai perusahaan merupakan persepsi investor terhadap tingkat keberhasilan perusahaan yang sering dilakukan dengan harga saham (Sujoko dan Soebiantoro, 2007; Dwiaji, 2011). Harga saham yang tinggi akan membuat nilai perusahaan juga tinggi. Nilai perusahaan yang tinggi akan membuat pasar percaya tidak hanya pada kinerja perusahaan saat ini namun juga pada prospek dimasa depan. Dalam penelitian ini, nilai perusahaan diukur dengan Price to Book Value (PBV), karena perusahaan yang berjalan dengan baik umumnya mempunyai rasio PBV di atas satu, yang menunjukkan bahwa nilai pasar saham lebih besar dari nilai bukunya.Menurut Husnan (2008:67) dalam Lisnandy (2016) nilai pasar saham dan nilai buku atau disebut dengan Price to Book Value dapat digunakan untuk mengukur nilai perusahaan.Semakin besar rasio PBV semakin tinggi perusahaan dinilai oleh pemodal (investor).

\subsection{Teori Keagenan (Agency Theory)}

Teori agensi berawal dari adanya penelitian yang dilakukan oleh Jensen dan Meckling padatahun 1976 yang mengacu pada tujuan utama dari manajemen keuangan yaitu memaksimalkan kekayaan dan kesejahteraan pemegang saham. Dalam teori keagenan, hubungan agensi muncul ketika satu orang atau lebih memperkerjakan orang lain untuk memberikan suatu jasa dan kemudian mendelegasikan wewenang keputusan kepada agen tersebut. Hubungan antara principal dan agen dapat mengarah pada kondisi ketidakseimbangan informasi (asymmetrical information) karena agen berada pada posisi yang memiliki informasi yang lebih banyak tentang perusahaan dibandingkan dengan principal (Arifin, 2007:47).

\subsection{Biaya Keagenan (Agency Cost)}

Permasalahan yang merupakan akibat dari perbedaan kepentingan antara manajer dengan pemegang saham disebut dengan agency problem. Masalah keagenan (Agency problem) menimbulkan pengeluaran perusahaan untuk mencegah pihak manajemen perusahaan melakukan penyalahgunaan wewenang untuk mengutamakan kepentingannya. Oleh karena itu, diperlukan suatu mekanisme pengawasan atau 
pemantauan untuk meminimumkan konflik kepentingan antara manajer dengan pemegang saham. Dimana biaya yang harus dikeluarkan pemilik untuk mengawasi dan memonitor kinerja manajemen sehingga mereka bekerja untuk kepentingan perusahaan disebut sebagai Agency cost. Menurut Jensen dan Meckling (1976) dalam pamungkas (2016) pengertian biaya agensi (Agency cost) adalah Jumlah dari biaya yang dikeluarkan principal untuk melakukan pengawasan terhadap agen.

\subsection{Kebijakan Dividen(Dividend Policy)}

Dividen adalah bagian laba perusahaan yang dibagikan kepada pemegang saham.Besarnya dividen yang dibagikan kepada pemegang saham tergantung pada jumlah lembar saham yang dimiliki pemegang saham.Nilai dan waktu pembayaran dividen ditentukan oleh Rapat Umum Pemegang Saham (RUPS), dan nilai yang dibagikan berkisar antara nol hingga sebesar laba bersih tahun berjalan atau tahun lalu.Dividen merupakan aliran kas yang dibayarkan kepada para pemegang saham, besar rasio pembayaran dividen tunai kepada para pemegang saham ditunjukkan melalui Dividend Payout Ratio.

Dividend Payout Ratio(DPR) adalah perbandingan antara dividen yang dibayarkan dengan laba bersih yang didapat dan biasanya disajikan dalam bentuk persentase. Semakin tinggi DPRakan menguntungkan para investor tetapi dari pihak perusahaan akan memperlemah internal financing karena memperkecil laba ditahan(Retained earning), sebaliknya DPRsemakin kecil akan merugikan para pemegang saham (Stockholders) tetapi internal financing perusahaan semakin kuat.

\subsection{Leverage}

Alternatif kebijakan pendanaan perusahaan dapat berupa leverage keuangan (hutang) yang dapat digunakan untuk melakukan pembiayaan disektor unit usaha. Hutang merupakan salah satu sumber pembiayaan eksternal yang digunakan oleh perusahaan untuk membiayai kebutuhan dananya. Menurut Munawir (2002:18) hutang adalah semua kewajiban keuangan perusahaan kepada pihak lain yang belum terpenuhi, dimana utang merupakan sumber dana atau modal perusahaan yang berasal dari kreditur. Kebijakan hutang perusahaan dapat dilihat dari rasio leverage.

Rasio leverage yaitu rasio yang mengukur sampai seberapa jauh aktiva perusahaan dibiayai dari hutang. Semakin tinggi leverage menunjukkan semakin tinggi modal pinjaman (hutang) yang digunakan perusahaan didalam menghasilkan keuntungan (Tanuwijaya, 2011; Hertiana, 2016).Dalam penelitian ini kebijakan hutang diproksikandengan Debt to Equity Ratio(DER) yang mengukur sampai seberapa jauh ekuitas perusahaan dibiayai dari hutang.

\section{Rerangka Konseptual Dan Pengembangan Hipotesis \\ 4.1. Rerangka Konseptual}

Berdasarkan latar belakang, tujuan penelitian dan landasan teori yang telah diuraikan sebelumnya, maka rerangka konseptual dalam penelitian ini adalah sebagai berikut : 


\section{Gambar 1 \\ Rerangka Konseptual \\ $\mathrm{H}_{3}$}

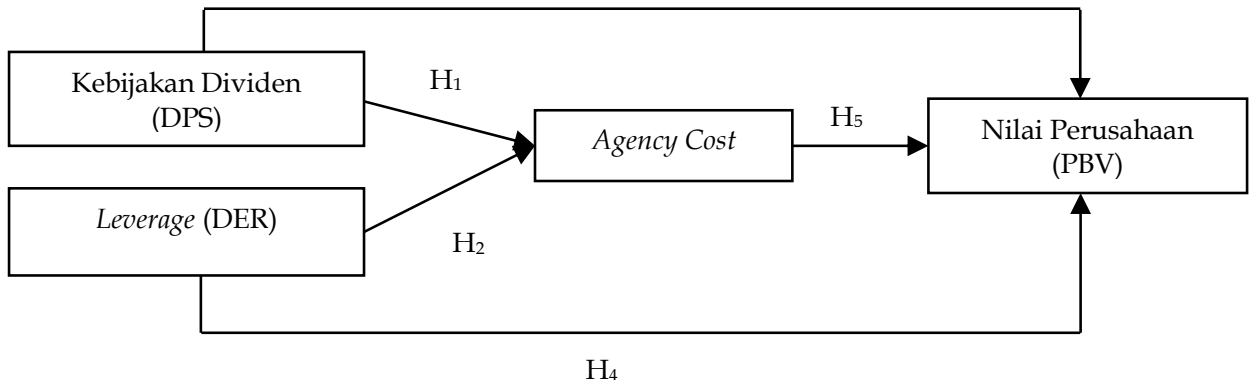

\subsection{Pengembangan Hipotesis}

\subsubsection{Pengaruh Kebijakan Dividen terhadap Agency Cost}

Pada dasarnya, laba bersih (Earning After Tax) perusahaan dapat dibagikan kepada pemegang saham sebagai dividen atau ditahan dalam bentuk laba ditahan untuk membiayai investasi perusahaan. Kebijakan dividen berkaitan dengan kebijakan mengenai seberapa besar laba yang diperoleh perusahaan akan didistribusikan kepada pemegang saham (Sofyaningsih dan Hardiningsih, 2011; Triwahyuni, 2016). Keputusan pembagian dividen ditentukan oleh pemegang saham melalui RUPS memberikan konsekuensi bahwa besar kecilnya dividen dapat dijadikan alat bagi pemegang saham untuk mengendalikan manajemen.

Hubungan keagenan antara pemilik perusahaan dengan manajemen menciptakan kesempatan bagi manajemen untuk mengejar tujuan pribadinya di samping memaksimalkan kesejahteraan pemilik.Schooley et al. (1994) dalam Muttaqien (2010) mengungkapkan bahwa kebijakan dividen digunakan untuk menurunkan biaya keagenan.Pembayaran dividen menyebabkan jumlah dana yang dikelola oleh perusahaan semakin kecil. Investor akan melihat kenaikan dividen sebagai sinyal positif atas prospek perusahaan di masa depan, sehingga investor tertarik untuk membeli saham perusahaan tersebut. Semakin tingginya pembagian dividen yang dilakukan perusahaan dapat mengurangi agency cost, karena pembagian dividen yang besar dapat mengurangi laba ditahan sehingga dapat membuat perusahaan menggunakan dana eksternal. Putri (2015), Pamungkas (2016) dan Triwahyuni (2016) menemukan bahwa kebijakan dividen memiliki pengaruh negatif signifikan terhadap Agency cost. Berdasarkan argumentasi teoritik dan berbagai hasil penelitian diatas maka dapat dirumuskan hipotesis sebagai berikut:

$\mathrm{H}_{1}$ : Kebijakan dividen berpengaruh negatif terhadap agency cost

\subsubsection{Pengaruh Leverage terhadap Agency Cost}

Leverage akan mengurangi konflik antara pemegang saham dengan manajemen.Leverage adalah penggunaan asset dan sumber dana oleh perusahaan dengan maksud agar meningkatkan potensi keuntungan pemegang saham (Sartono, 2001; Putri, 2015).Semakin besar utang maka perusahaan harus mencadangkan lebih banyak kas untuk membayar bunga dan pokok pinjaman. Dalam hal ini adanya hutang akan dapat mengendalikan penggunaan free cash flow secara berlebihan oleh manajemen. Hal tersebut menyebabkan agency cost berkurang. Menurut Putri (2015) menambah utang dapat mengurangi masalah keagenan karena dua alasan.Pertama, penambahan hutang dalam struktur modal mengurangi penggunaan saham sehingga mengurangi biaya keagenan ekuitas.Kedua, perusahaan memiliki kewajiban untuk mengembalikan pinjaman dan membayar beban bunga secara periodik. Oleh karena itu, dengan semakin besar utang perusahaan maka semakin kecil dana menganggur (Idle fund) yang dapat digunakan manajer untuk pengeluaran-pengeluaran yang kurang perlu. Hasil penelitian Putraet. al 
(2004) dan Putri (2015) menunjukkan bahwaleverage berpengaruh negatif terhadap Agency cost.

$\mathrm{H}_{2}$ : Leverage berpengaruh negatif terhadap Agency cost

\subsubsection{Pengaruh Kebijakan Dividen terhadap Nilai Perusahaan}

Menurut Haryanti (2011) kenaikan pembayaran dividen dapat dilihat sebagai suatu sinyal bahwa perusahaan memiliki prospek atau masa depan yang cerah. Demikian sebaliknya, apabila pembayaran dividen turun atau ditiadakan sama sekali, maka hal ini akan dipandang sebagai prospek perusahaan yang buruk. Oleh karena itu perusahaan harus dapat memperhatikan tentang kebijakan dividennya, sebab investor akan menilai lebih kepada perusahaan yang melakukan pembayaran dividen dengan tepat dan teratur.

Besarnya dividen yang dibagikan kepada para pemegang saham akan menjadi daya tarik bagi pemegang saham karena sebagian investor cenderung lebih menyukai dividen dibandingkan dengan Capital gain karena dividen bersifat lebih pasti. TemuanWijaya et. al (2010), Haryanti (2011) dan Tansil (2015) menunjukkan bahwa kebijakan dividen berpengaruh positif signifikan terhadap nilai perusahaan.

$\mathrm{H}_{3}$ : Kebijakan dividen berpengaruh positif terhadap nilai perusahaan

\subsubsection{Pengaruh Leverage terhadap Nilai Perusahaan}

Menurut teori sinyal (Signalling Theory), sebuah perusahaan yang sangat menguntungkan akan mencoba untuk menghindari penjualan saham dan lebih memilih mendapatkan modal baru dengan cara lain, termasuk menggunakan hutang (Brigham \& Houston, 2006 : 39). Perusahaan yang mengumumkan meningkatkan penggunaan hutang berpengaruh positif terhadap harga saham. Perusahaan yang meningkatkan proporsi penggunaan hutang berarti bahwa peningkatan leverage dinilai memberikan manfaat bagi pemodal (Husnan \& Pudjiastuti, 2006 ; Hertiana, 2016). Tingkat leverage yang tinggi memperlihatkan nilai hutang yang besar, dengan hutang yang besar, dimana hutang itu dapat dijadikan modal untuk memutar kegiatan perusahaan untuk mendapat laba yang nantinya akan meningkatkan nilai perusahaan (Rakhimsyah dan Gunawan, 2011; Hertiana, 2016).

Perusahaan yang mempunyai tingkat hutang yang tinggi akan dapat meningkatkan nilai perusahaan karena investor menilai bahwa perusahaan yang mempunyai hutang besar mengindikasikan perusahaan tersebut juga berskala besar. Sehingga investor akan menanamkan modalnya dan akan mendapatkan pengembalian yang besar pula yang selanjutnya akan meningkatkan nilai perusahaan. Hasil penelitian Rustendi dan Jimmi (2008), Haryanti (2011), Hermuningsih (2013), Ambarwati dan Stephanus (2014), Tansil (2015), dan Hertiana (2016) menunjukkan bahwa leverage berpengaruh positif terhadap nilai perusahaan.

$\mathrm{H}_{4}$ : Leverage berpengaruh positif terhadap nilai perusahaan

\subsubsection{Pengaruh Agency Cost berpengaruh terhadap Nilai Perusahaan}

Menurut Agency theory yang disebut principal adalah pemegang saham dan yang dimaksud agen adalah manajemen yang mengelola perusahaan. Dalam manajemen keuangan, tujuan utama perusahaan adalah memaksimalkan nilai perusahaan yang berarti juga memaksimalkan kemakmuran pemegang saham. Untuk itu para manajer yang diangkat oleh pemegang saham harus bertindak untuk kepentingan pemegang saham, tetapi ternyata sering ada konflik antara manajer dan pemegang saham yang akan menyebabkan adanya agency cost.

Menurut Jensen dan Meckling (1976), bahwa dalam teori agensi siapapun yang menimbulkan biaya agensi, biaya yang timbul pasti merupakan tanggungan pemegang saham. Semakin besar peluang timbulnya biaya agensi semakin rendah nilai perusahaan. Agency cost yang rendah dapat meningkatkan nilai perusahaan, karena investor menganggap bahwa perusahaan tersebut dapat meminimalisir konflik yang ada diantara manajer dan pemegang saham sehingga kinerja perusahaan dapat meningkat. Temuan 
dalam penelitian Haryanti (2011), Tansil (2015), dan Hertiana (2016) menunjukkan bahwa agency cost berpengaruh negatif terhadap nilai perusahaan.

$\mathrm{H}_{5}$ :Agency cost berpengaruh negatif terhadap nilai perusahaan

\subsubsection{Pengaruh tidak langsung Kebijakan Dividen dan Leverage terhadap Nilai Perusahaan melalui Agency Cost sebagai Variabel Intervening}

Sebagaimana telah dipaparkan sebelumnya bahwa leverage dan kebijakan dividen memiliki pengaruh terhadap Agency cost dan kedua variabel tersebut juga memiliki pengaruh terhadap nilai perusahaan (Firm value) secara langsung. Leverage dan kebijakan dividen juga akan berpengaruh terhadap nilai perusahaan melalui agency cost sebagai intervening variable. Hal ini berarti bahwa semakin tinggi tingkat hutang dan pembagian dividen dapat berpengaruh terhadap nilai perusahaan jika dikaitkan dengan Agency cost yang diproksikan dengan total asset terhadap penjualan bersih maka dengan adanya hutang dan kebijakan dividen akan menurunkan biaya agensi. Dengan meningkatnya leverage yang dibiayai dengan hutang dan pembagian dividen maka dapat meminimalisir agency cost dan selanjutnya akan meningkatkan nilai perusahaan.

$\mathrm{H}_{6 \mathrm{a}}$ : Kebijakan dividen berpengaruh positif tidak langsung terhadap nilai perusahaan melalui agency cost sebagai variabel intervening.

$\mathrm{H}_{6 \mathrm{~b}}$ : Leverage berpengaruh positif tidak langsung terhadap nilai perusahaan melalui agency cost sebagai variabel intervening.

\section{Metode Penelitian}

5.1. Jenis Penelitian

Jenis penelitian yang digunakan dalam penelitian ini adalah penelitian asosiatif. Menurut Sugiyono (2013 : 11) penelitian asosiatif merupakan penelitian yang bertujuan mengetahui hubungan antara dua variabel atau lebih.

\subsection{Populasi dan Sampel Penelitian}

Populasi dalam penelitian ini berjumlah sebanyak 42 perusahaan manufaktur pada sektor Industri Barang Konsumsi yang terdaftar di BEIperiode 2012-2016.Metode penentuan sampel yang digunakan adalah purposive sampling, yaitu teknik penentuan sampel dengan menggunakan pertimbangan tertentu.Dengan demikian, terpilih 14 sampel penelitian.

\subsubsection{Identifikasi Variabel}

\subsection{Identifikasi dan Klasifikasi Variabel}

Variabel-variabel dalam penelitian ini dapat diidentifikasi sebagai berikut :

1. Nilai perusahaan yang diproksikan denganPrice to Book Value (PBV)

2. Kebijakan dividen diproksikan dengan Dividend Per Share(DPS)

3. Leveragediproksikan dengan Debt to Equity Ratio(DER)

4. Agency costdiproksikan dengan Efektivitas.

\subsubsection{Klasifikasi Variabel}

Berdasarkan identifikasi variabel di atas, maka variabel-variabel tersebut dapat diklasifikasikan sebagai berikut :

1. Variabel Dependen

Dalam penelitian ini yang menjadi variabel dependen adalah nilai perusahaan $(Y)$.

2. Variabel Independen

Variabel independen dalam penelitian ini adalah kebijakan dividen $\left(\mathrm{X}_{1}\right)$ dan leverage $\left(\mathrm{X}_{2}\right)$. 
3. Variabel Intervening

Variabel intervening adalah variabel yang mempengaruhi hubungan antara variabel independen dengan variabel dependen menjadi hubungan yang tidak langsung. Dalam penelitian ini yang menjadi variabel intervening adalah Agency $\operatorname{cost}(\mathrm{Z})$.

\subsection{Definisi Operasional Variabel}

\subsubsection{Nilai Perusahaan (Price to Book Value/PBV)}

Price to Book Value (PBV) merupakan perbandingan antara harga per lembar saham dengan nilai buku per lembar saham yang dinyatakan dalam Rupiah (Rp).PBV dapat ditentukan dengan formula (Husnan, 2008) sebagai berikut :

$$
\begin{gathered}
\qquad B V=\frac{\text { Harga pasar per lembar saham }}{\text { Nilai buku per lembar saham }} \\
\text { Nilai Buku per Lembar Saham }=\frac{\text { Ekuitas }}{\text { Jumlah saham yang beredar }}
\end{gathered}
$$

\subsubsection{Kebijakan Dividen (Dividend Per Share/DPS)}

Dividend Per Share (DPS) adalah total dividen yang dibayarkan dengan jumlah saham biasa yang beredar yang dinyatakan dalam Rupiah (Rp). DPS ditentukan dengan formula (Husnan, 2008) sebagai berikut :

$$
\text { DPS }=\frac{\text { Total dividen yang dibayarkan }}{\text { Jumlah Saham Biasa }}
$$

\subsubsection{Leverage (Debt to Equity Ratio/DER)}

Debt to Equity Ratio (DER) adalah perbandingan antara total hutang dengan modal sendiri yang dinyatakan dalam persentase (\%). DER dapat ditentukan dengan formula (Husnan, 2008) sebagai berikut :

\subsubsection{Agency Cost(Efektivitas)}

$$
D E R=\frac{\text { Total Hutang }}{\text { Modal Sendiri }} \times 100
$$

Agency cost (biaya keagenan) diukur berdasarkan efektivitas manajemen perusahaan dalam menggunakan assetnya. Agency Cost (AC) yaitu perbandingan antara total asset dengan penjualan bersih perusahaan.

$$
A C=\frac{\text { Total Assets }}{\text { Sales }}
$$

\subsection{Prosedur Analisis Data}

Pengujian hipotesis dalam penelitian ini menggunakan analisis jalur (Path analysis). Teknik analisis jalur ini akan digunakan dalam menguji besarnya sumbangan (kontribusi) yang ditunjukkan oleh koefisien jalur pada setiap diagram jalur dari hubungan kausal antar variabel $\mathrm{X}_{1}$, dan $\mathrm{X}_{2}$ terhadap $\mathrm{Y}$ serta berdampak terhadap $\mathrm{Z}$. Jadi, model path analysis digunakan untuk menganalisis hubungan antara variabel dengan tujuan untuk mengetahui pengaruh langsung atau tidak langsung seperangkat variabel bebas terhadap variabel terikat (Riduwan dan Kuncoro, 2014:116).

Menurut Baron dan Kenny (1968)dalam Ghozali (2013) suatu variabel disebut mediator jika variabel tersebut ikut mempengaruhi hubungan antara variabel independen dan variabel dependen. Adanya pengaruh variabel mediasi dapat dideteksi secara langsung. Syarat dikatakannya sebagai variabel intervening (mediasi) adalah dengan persamaan regresi sebagai berikut :

$$
\begin{aligned}
& Y=a_{1}+a_{1} X_{1}+a_{2} X_{2} \\
& Z=a_{2}+b_{1} X_{1}+b_{2} X_{2} \\
& Y=a_{3}+c Z
\end{aligned}
$$

Variabel $\mathrm{Z}$ disebut sebagai mediator atau intervening jika persamaan (1.1) $\mathrm{X}_{1}$ dan $\mathrm{X}_{2}$ secara signifikan mempengaruhi $Y\left(a_{1} \neq 0\right.$ dan $\left.a_{2} \neq 0\right)$, persamaan (1.2) $X_{1}$ dan $X_{2}$ secara 
signifikan mempengaruhi $Z\left(b_{1} \neq 0\right.$ dan $\left.b_{2} \neq 0\right)$, dan persamaan (1.3) $Z$ secara signifikan mempengaruhi $Y($ atau $c \neq 0)$.

Uji sobel dilakukan dengan cara menguji kekuatan pengaruh tidak langsung $X$ ke $Y$ melalui $Z$. pengaruh tidak langsung $X$ ke $Y$ lewat $Z$ dihitung dengan cara mengalikan jalur $\mathrm{X}$ ke $\mathrm{Z}\left(\mathrm{p}_{2}\right)$ dengan jalur $\mathrm{Z}$ ke $\mathrm{Y}\left(\mathrm{p}_{3}\right)$ atau $\mathrm{p}_{2} \mathrm{p}_{3}$. Standard error koefisien $\mathrm{p}_{2}$ dan $\mathrm{p}_{3}$ ditulis dengan $\mathrm{Sp}_{2}$ dan $\mathrm{Sp}_{3}$ dan besarnya standard error pengaruh tidak langsung (indirect effect) adalah $\mathrm{Sp}_{2} \mathrm{p}_{3}$ yang dihitung dengan rumus di bawah ini:

$$
\mathrm{Sp} 2 \mathrm{p} 3=\sqrt{\mathrm{p}^{2} \mathrm{sp} 2^{2}+\mathrm{p} 2^{2} \mathrm{sp} 3^{2}+\mathrm{sp} 2^{2} \mathrm{sp} 3^{2}}
$$

Untuk menguji signifikansi pengaruh tidak langsung, maka kita perlu menghitung nilai $t$ dari koefisien $\mathrm{P}_{2} \mathrm{P}_{3}$ dengan rumus sebagai berikut :

$$
\mathrm{t} \text { hitung }=\frac{p 2 p 3}{s p 2 p 3}
$$

Nilai $\mathrm{t}$ hitung ini dibandingkan dengan nilai $\mathrm{t}$ tabel, jika nilai $\mathrm{t}$ hitung $>$ nilai $\mathrm{t}$ tabel maka dapat disimpulkan terjadi pengaruh mediasi yang signifikan.

Berikut ini ditampilkan model analisis jalur hipotesis 6a dan hipotesis 6b:

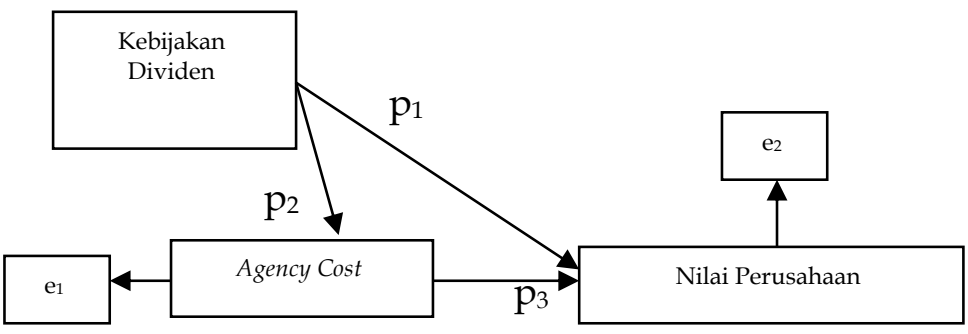

Gambar 2. Model Struktur Analisis Jalur Hipotesis 6a

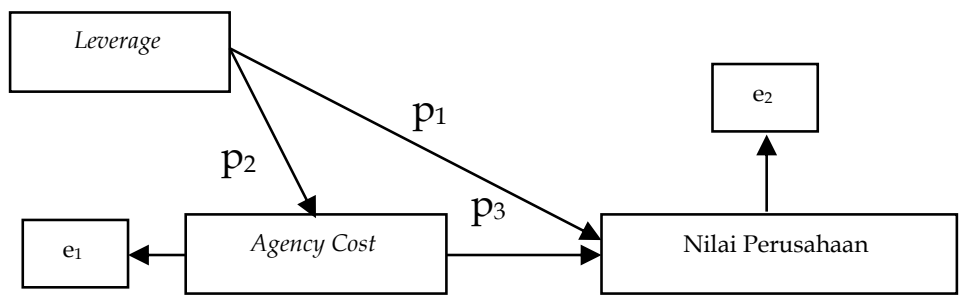

Gambar 3. Model Struktur Analisis Jalur Hipotesis 6b

$\mathrm{e}_{1}$ menunjukkan jumlah variance variabel agency cost yang tidak dijelaskan oleh variabel kebijakan dividen dan leverage. Sedangkan $\mathrm{e}_{2}$ menunjukkan jumlah variance variabel nilai perusahaan yang tidak dijelaskan oleh variabel kebijakan dividen dan leverage. Untuk mencari besarnya $\mathrm{e}_{1}$ dan $\mathrm{e}_{2}$ digunakan rumus (Ghozali, 2013:251) sebagai berikut :

$$
\begin{aligned}
& e 1=\sqrt{1-R^{2}} \\
& e 2=\sqrt{1-R^{2}}
\end{aligned}
$$

Koefisien jalur dihitung dengan membuat dua persamaan struktural, yaitu persamaan regresi yang menunjukkan hubungan yang dihipotesiskan. Dalam penelitian ini persamaan yang digunakan dalam analisis jalur adalah sebagai berikut :

Persamaan regresi Hipotesis 6a :

(1) $\mathrm{AC}=\mathrm{a}+\mathrm{aDPS}+\mathrm{e}_{1}$

(2) $\mathrm{PBV}=a+b D P S+c A C+e_{2}$

Persamaan regresi Hipotesis $6 \mathrm{~b}$ :

(1) $\mathrm{AC}=\mathrm{a}+\mathrm{aDER}+\mathrm{e}_{1}$

(2) $\mathrm{PBV}=\mathrm{a}+\mathrm{bDER}+\mathrm{cAC}+\mathrm{e}_{2}$ 


\section{Hasil dan Pembahasan}

\subsection{Pengaruh kebijakan dividen terhadap Agency Cost}

Pengujian hipotesis pertama $\left(\mathrm{H}_{1}\right)$ dilakukan dengan analisis regresi sederhana, yang hasilnya dapat dilihat pada tabel berikut :

Tabel 2. Ringkasan Hasil Regresi Hipotesis 1

\begin{tabular}{|c|c|c|c|c|c|c|c|}
\hline Variabel & \multicolumn{2}{|c|}{ Harga $\mathrm{r}$ dan $\mathrm{r}^{2}$} & \multicolumn{2}{c|}{ Harga $\mathrm{t}$} & Sig. & Koefisien & Konstanta \\
\cline { 2 - 5 } & $\mathrm{R}$ & $\mathrm{r}^{2}$ & $\mathrm{t}$ hitung & $\mathrm{t}$ tabel & & & \\
\hline LnDps & 0,422 & 0,178 & -3.838 & 2,2281 & 0,000 & $-0,070$ & 0,068 \\
\hline
\end{tabular}

Dependent Variable : LnAc

Sumber : Output SPSS

Berdasarkan tabel 1 diketahui persamaan regresi sederhana sebagai berikut :

$$
\text { LnAC }=0,068-0,070 \mathrm{DPS}
$$

Berdasarkan tabel 2di atas diperoleh nilai koefisien korelasi 0,422 dan nilai t hitung menunjukkan nilai $-3,838$ lebih besar dari nilai t tabel $(2,2281)$, dengan signifikan 0,000 . Hal ini berarti bahwa kebijakan dividen (DPS) berpengaruh negatif signifikan terhadap Agency Cost.dengan demikian, hipotesis pertama $\left(\mathrm{H}_{1}\right)$ dalam penelitian ini diterima(Accepted).

Semakin tingginya pembagian dividen yang dilakukan perusahaan dapat mengurangi agency cost, karena pembagian dividen yang besar dapat mengurangi laba ditahan sehingga dapat membuat perusahaan menggunakan dana eksternal. Penambahan dana eksternal menyebabkan kinerja manajer dapat diawasi oleh pihak pemberi dana sehingga manajer akan melakukan tindakan sesuai dengan tujuan yang telah ditetapkan perusahaan.Hasil penelitan inimendukung temuan Putri (2015), Pamungkas (2016) dan Triwahyuni (2016).Namun demikian, temuan dalam penelitian ini berbeda dengan temuan Muttaqien (2010).

\subsection{Pengaruh Leverage terhadap Agency Cost}

Tabel 3. Ringkasan Hasil Regresi Hipotesis 2

\begin{tabular}{|c|c|c|c|c|c|c|c|}
\hline \multirow[t]{2}{*}{ Variabel } & \multicolumn{2}{|c|}{ Harga $r$ dan $r^{2}$} & \multicolumn{2}{|c|}{ Harga $t$} & \multirow[t]{2}{*}{ Sig. } & \multirow[t]{2}{*}{ Koefisien } & \multirow[t]{2}{*}{ Konstanta } \\
\hline & $\mathrm{R}$ & $\mathrm{r}^{2}$ & thitung & t table & & & \\
\hline DER & 0,272 & 0,074 & 2,327 & 2,2281 & 0,023 & $-0,157$ & $-0,157$ \\
\hline
\end{tabular}

Dependent Variable: LnAc

Sumber : Output SPSS

Berdasarkan tabel 3 diperoleh persamaan regresi sederhana sebagai berikut :

$$
\text { LnAc }=-0,157-0,157 \mathrm{DER}
$$

Pengujian hipotesis kedua menunjukkan nilai koefisien korelasi 0,272 dan perolehan nilai $t$ hitung sebesar2,327 lebih besar dari nilai $t$ tabel $(2,2281)$, dengan signifikansi 0,023 . Hal ini mengindikasikan bahwa leverage (DER) berpengaruh negatif dan signifikan terhadap Agency cost.Sehingga hipotesis kedua diterima.Temuan dalam penelitian ini selaras dengan teori Jensen dan Meckling (1976) yang menyatakan bahwa dengan pengurangan free cash flow melalui peningkatan hutang dapat mengurangi masalah agensi antara pemegang saham dengan manajemen. Hal itu terjadi karena jumlah dana yang menganggur semakin kecil yang akan mengurangi pengawasan terhadap manajemen semakin berkurang karena pihak ketiga (debtholder) akan ikut mengawasi manajemen atas dana yang dipinjamkan. Hasil penelitan inijuga mendukung penelitian sebelumnya yang dilakukan oleh Putra et. al (2004) dan Putri (2015) dan tidak sejalan dengan temuandalam penelitian Muttaqien (2010). 


\subsection{Pengaruh Kebijakan Dividen terhadap Nilai Perusahaan}

Tabel 4. Ringkasan Hasil Regresi Hipotesis 3

\begin{tabular}{|c|c|c|c|c|c|c|c|}
\hline \multirow[t]{2}{*}{ Variabel } & \multicolumn{2}{|c|}{ Harga $\mathrm{r}$ dan $\mathrm{r}^{2}$} & \multicolumn{2}{|c|}{ Harga $t$} & \multirow[t]{2}{*}{ Sig. } & \multirow[t]{2}{*}{ koefisien } & \multirow[t]{2}{*}{ Konstanta } \\
\hline & $\mathrm{R}$ & $\mathrm{r}^{2}$ & thitung & $\mathrm{t}$ table & & & \\
\hline LnDps & 0,291 & 0,085 & 2,513 & 2,2281 & 0,014 & 0,180 & 0,666 \\
\hline
\end{tabular}

Dependent Variable : LnPBV

Sumber : Output SPSS

Mengacu pada tabel 4 di atasdidapatkan persamaan regresi sederhana, yaitu :

LnPBV = 0,666 + 0,180DPS

Berdasarkan hasil pengujian hipotesis ketiga $\left(\mathrm{H}_{3}\right)$ diperoleh nilai koefisien korelasi 0,291 dan nilai t hitung sebesar 2,513> nilai t tabel 2,2281, dengan signifikansi 0,023 nilai signifikansi sebesar 0,014 lebih kecil dibandingkan $\alpha=0,05(0,014<a=0,05)$. Hal ini berarti bahwa pengaruh yang terjadi antara variabel kebijakan dividen (DPS) dengan nilai perusahaan (PBV) adalah positif dan signifikan.Dengan demikian,hipotesis ketiga dalam penelitian ini diterima.Hal ini juga sesuai denganteori kebijakan dividen relevan yang menyatakan bahwa perusahaan akan membayar dividen yang besar kepada pemegang saham karena dapat meningkatkan nilai perusahaan. Teori ini didukung dengan penelitian pada perusahaan yang dinilai berdasarkan aliran kas yang akan diterima oleh pemegang saham. Menurut teori Bird in the hand, pemegang saham lebih menyukai pembagian dividen saat ini dibandingkan dengan dividen yang akan dibagikan di masa yang akan datang dan capital gains (Gordon \&Lintner, 1956; Bhattacharya, 1979; Wijaya et. al, 2010). Sesuai dengan Signaling theory, pembayaran dividen berisi informasi/isyarat tentang prospek perusahaan di masa yang akan datang (Rozeff, 1982; Wijaya et. al, 2010). Pengumuman meningkatnya dividen telah meningkatkan return saham dan dapat digunakan untuk menangkal isu yang tidak diharapkan perusahaan di masa yang akan datang.

Hasil penelitan ini mendukung penelitian sebelumnya yang dilakukan Haryanti (2011) dan Tansil (2015) yang menyatakan bahwa kebijakan dividen berpengaruh positif signifikan terhadap nilai perusahaan.Namun hasil penelitian initidak sejalandengan temuan Sukirni (2012).

\subsection{Pengaruh Leverage terhadap Nilai Perusahaan}

Tabel 5.Ringkasan Hasil Regresi Hipotesis 4

\begin{tabular}{|c|c|c|c|c|c|c|c|}
\hline \multirow[t]{2}{*}{ Variabel } & \multicolumn{2}{|c|}{ Harga $\mathrm{r}$ dan $\mathrm{r}^{2}$} & \multicolumn{2}{|c|}{ Harga $t$} & \multirow[t]{2}{*}{ Sig. } & \multirow[t]{2}{*}{ koefisien } & \multirow[t]{2}{*}{ Konstanta } \\
\hline & $\mathrm{R}$ & $\mathrm{r}^{2}$ & thitung & t table & & & \\
\hline DER & 0,341 & 0,116 & 2,990 & 2,2281 & 0,004 & 0,733 & 0,969 \\
\hline
\end{tabular}

Dependent Variable: LnPBV

Sumber : Output SPSS

Berdasarkan tabel 5 dapat disusun persamaan regresi sederhana sebagai berikut :

LnPBV $=0,969+0,733$ DER

Berdasarkan Output SPSSdi atas diketahui nilai sig. sebesar 0,004<0,05 dengan nilai $\mathrm{r}$ sebesar 0,341 dan $\beta=+0,733$. Dengan demikian dapat disimpulkan bahwa pengaruh leverage (DER) terhadap nilai perusahaan(PBV) adalah positif dan signifikan. Dengan demikian, hipotesis keempat $\left(\mathrm{H}_{4}\right)$ yang diajukan dalam penelitian ini terbukti dan diterima(Accepted).Hasil penelitian ini sesuai dengan teori Modigliani dan Miller yang menyatakan bahwa peningkatan hutang dapat meningkatkan nilai perusahaan apabila belum mencapai titik optimalnya. Hal ini juga diperkuat oleh Trade-off Theory yang menjelaskan bahwa jika posisi struktur modal berada di bawah titik optimal maka setiap penambahan hutang akan meningkatkan nilai perusahaan. Hal ini menunjukkan bahwa kebijakan penambahan hutang merupakan sinyal positif bagi investor dan mempengaruhi nilai perusahaan. Bagi perusahaan, adanya hutang dapat membantu untuk mengendalikan penggunaan dana kas secara bebas dan berlebihan oleh pihak manajemen. 
Hasil penelitian ini mendukung penelitian Rustendi dan Jimmi (2008), Haryanti (2011), Hermuningsih (2013), Ambarwati dan Stephanus (2014), Tansil (2015), dan Hertiana (2016) yang menyatakan bahwa leverage yang diproksikan dengan DER berpengaruh positif dan signifikan terhadap nilai perusahaan. Namun demikian, temuan ini berbeda dengan temuan Umi, Gatot dan Ria (2012).

\subsection{Pengaruh Agency Cost terhadap Nilai Perusahaan} Tabel 6. Ringkasan Hasil Regresi Hipotesis 5

\begin{tabular}{|c|c|c|c|c|c|c|c|}
\hline Variabel & \multicolumn{2}{|c|}{ Harga $\mathrm{r}$ dan $\mathrm{r}^{2}$} & \multicolumn{2}{c|}{ Harga $\mathrm{t}$} & \multirow{2}{*}{ Sig. } & koefisien & Konstanta \\
\cline { 2 - 5 } & $\mathrm{R}$ & $\mathrm{r}^{2}$ & $\mathrm{t}$ hitung & $\mathrm{t}$ tabel & & & \\
\hline LnAc & 0,540 & 0,291 & $-5,288$ & 2,2281 & 0,000 & $-2,007$ & 1,003 \\
\hline
\end{tabular}

Dependent Variable : LnPBV

Sumber : Output SPSS

Berdasarkan tabel 6 di atas diketahui persamaan regresi sederhananyaadalah :

$$
\mathrm{PBV}=1,003-2,007 \mathrm{LnAC}
$$

Berdasarkan tabel 6 nampak nilai sig. sebesar $0,000<\alpha=0,05$ dengan nilai koefisien regresi $(\beta)$ sebesar-2,007 menunjukkan arah yangnegatif. Dengan demikian, dapat disimpulkan bahwa Agency costberpengaruh negatif dan signifikan terhadap nilai perusahaan $(\mathrm{PBV})$. Sehingga hipotesis kelima $\left(\mathrm{H}_{5}\right)$ terbukti dan diterima.Menurut Jensen dan Meckling (1976) bahwa dalam teori agensi (Agency Theory) dinyatakan siapa pun yang menimbulkan biaya agensi, biaya yang timbul pasti merupakan tanggungan pemegang saham.Semakin besar peluang timbulnya biaya agensi semakin rendah nilai perusahaan.Agency cost yang rendah dapat meningkatkan nilai perusahaan, karena investor menganggap bahwa perusahaan tersebut dapat meminimalisir konflik yang ada diantara manajer (Agent) dan pemegang saham (Principal) sehingga kinerja perusahaan dapat meningkat dan akhirnya nilai perusahaan juga akan meningkat.

Hasil penelitian ini mendukung penelitian yang dilakukan oleh Haryanti (2011), Tansil (2015) dan Hertiana (2016) yang mengatakan bahwa agency cost berpengaruhi negatif signifikan terhadap nilai perusahaan.Namun temuan dalam penelitian ini tidak sejalan dengan temuan Somantri et. al (2016).

\subsection{Pengaruh Kebijakan Dividen dan Leverage terhadap Nilai Perusahaan Melalui Agency Cost}

Berdasarkan hasil pengujian hipotesis sebelumnya $\left(\mathrm{H}_{1}\right.$ sampai dengan $\left.\mathrm{H}_{5}\right)$, diketahui bahwa kelima hipotesis tersebut diterima (Accepted) dan memenuhi syarat untuk dilakukannya pengujian intervening (mediasi).Dengan demikian, variabel Agency cost sebagai mediasi antara kebijakan dividen (DPS) dan leverage (DER) terhadap nilai perusahaan (PBV) dapat diuji. Dalam menguji pengaruh variabel intervening digunakan metode analisis jalur (Path analysis).Nilai koefisien jalur dapat dilihat pada tabel 7sebagai berikut :

\subsubsection{Uji Hipotesis 6a $\left(\mathrm{H}_{6 a}\right)$ :}

\section{Persamaan I}

$\operatorname{LnAC}=a+a \operatorname{anDPS}+\mathrm{e}_{1}$

Tabel 7. Ringkasan Hasil Uji Pengaruh Mediasi Persamaan I

\begin{tabular}{|c|c|c|c|c|c|c|c|}
\hline \multirow{2}{*}{ Model } & \multicolumn{2}{|c|}{ Unstandardized } & \multicolumn{2}{|c|}{ Harga $\mathrm{t}$} & \multicolumn{2}{c|}{ Sig. } & \multicolumn{2}{c|}{ Harga $\mathrm{r}$ dan $\mathrm{r}^{2}$} \\
\cline { 2 - 4 } & $\mathrm{B}$ & Std. Error & $\mathrm{t}$ hitung & $\mathrm{t}$ tabel & & $\mathrm{R}$ & $\mathrm{R}$ Square \\
\hline (Constanta) & 0,068 & 0,101 & 0,674 & 2,2281 & 0,503 & 0,422 & 0,178 \\
& $-0,070$ & 0,018 & $-3,838$ & & 0,000 & & \\
\hline
\end{tabular}

Dependent Variable: LnAC

Sumber : Output SPSS 
Berdasarkan Tabel 7 di atas diperoleh nilai unstandardized beta Dividend Per Share (DPS) sebesar -0,070 merupakan nilai path atau jalur p2 dan signifikan pada 0,000 yang berarti kebijakan dividen berpengaruh negatif terhadap Agency cost.

\section{Persamaan II}

$\operatorname{LnPBV}=a+b \operatorname{LnDPS}+c \operatorname{LnAC}+\mathrm{e}_{2}$

Tabel 8. Ringkasan Hasil Uji Pengaruh Mediasi Persamaan II

\begin{tabular}{|c|c|c|c|c|c|c|c|}
\hline \multirow[t]{2}{*}{ Model } & \multicolumn{2}{|c|}{ Unstandardized } & \multicolumn{2}{|c|}{ Harga $t$} & \multirow[t]{2}{*}{ Sig. } & \multicolumn{2}{|c|}{ Harga r dan r2 } \\
\hline & B & Std. Error & thitung & $t$ tabel & & $\mathrm{R}$ & R Square \\
\hline (Constanta) & 0,795 & 0,351 & 2,264 & \multirow[t]{2}{*}{2,2281} & 0,027 & \multirow[t]{2}{*}{0,544} & \multirow[t]{2}{*}{0,296} \\
\hline LnDPS & 0,048 & 0,070 & 0,686 & & 0,495 & & \\
\hline LnAc & $-1,886$ & 0,420 & $-4,486$ & & & & \\
\hline
\end{tabular}

Dependent Variable: LnPBV

Sumber : Data sekunder diolah

Berdasarkan tabel 8 diperoleh nilai unstandardized beta DPRsebesar0,048 merupakan nilai jalur path p1 dan signifikansi pada 0,495 yang berarti kebijakan dividen tidak berpengaruh terhadap nilai perusahaan (PBV). Selain itu, juga diperoleh nilai unstandardized beta Agency cost sebesar -1,886 merupakan nilai path p3 dan signifikansi pada 0,000 yang berarti Agency cost berpengaruh signifikan terhadap nilai perusahaan.

Berikut ini adalah analisis jalur untuk menguji hubungan antara kebijakan dividen (DPS) terhadap nilai perusahaan (PBV) dan apakah hubungan kebijakan dividen ke nilai perusahaan dimediasi oleh Agency cost dengan gambar di bawah ini :

\section{Gambar 4}

Path Analysis Kebijakan Dividen ke Nilai Perusahaan melalui Agency Cost

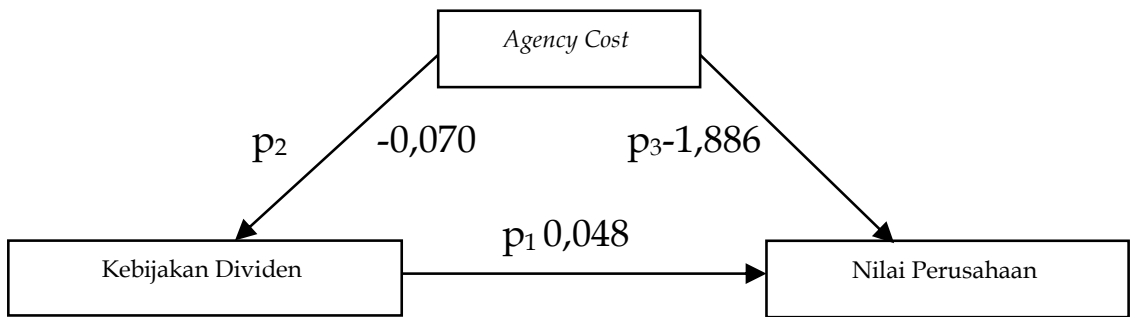

Tabel 9. Pengaruh Tidak Langsung dan Total

\begin{tabular}{|c|c|c|c|c|c|c|}
\hline $\begin{array}{c}\text { Variabel } \\
\text { Independen }\end{array}$ & $\begin{array}{c}\text { Variabel } \\
\text { Intervening }\end{array}$ & $\begin{array}{c}\text { Variabel } \\
\text { Dependen }\end{array}$ & $\begin{array}{c}\text { Pengaruh } \\
\text { Langsung }\end{array}$ & $\begin{array}{c}\text { Pengaruh } \\
\text { Tidak } \\
\text { Langsung }\end{array}$ & $\begin{array}{c}\text { Total } \\
\text { Effect }\end{array}$ & T Hitung \\
\hline $\begin{array}{c}\text { Kebijakan } \\
\text { Dividen }\end{array}$ & Agency Cost & $\begin{array}{c}\text { Nilai } \\
\text { Perusahaan }\end{array}$ & 0,048 & 0,13202 & 0,18002 & 2,8990 \\
\hline
\end{tabular}

Sumber : Output SPSS

Dari hasil uji sobel diperoleh nilai t-hitung pengaruh tidak langsung DPR terhadap PBV melalui Agency cost lebih besar dari t-tabel dengan tingkat signifikansi 0,05 yaitu sebesar 2,2281 maka dapat disimpulkan bahwa koefisien mediasi 0,13202 signifikan yang berarti Agency cost memediasi hubungan antara kebijakan dividen terhadap nilai perusahaan.Dengan demikian, hipotesis 6a yang menyatakan kebijakan dividen mempunyai pengaruh signifikan terhadap nilai perusahaan dengan agency cost sebagai variabel intervening terbukti. Agency cost dalam memediasi kebijakan dividen terhadap nilai perusahaan merupakan variabel mediasi sempurna (Perfect mediation) karena pengaruh langsung kebijakan dividen terhadap nilai perusahaan yang tadinya (sebelum memasukkan Agency cost) signifikan menjadi tidak signifikan setelah memasukkan variabel Agency cost ke dalam model persamaan regresi. 


\subsubsection{Uji Hipotesis $6 b\left(\mathrm{H}_{6 b}\right)$ : Persamaan I \\ $\operatorname{LnAC}=\alpha+a D E R+e_{1}$}

Tabel 10.Ringkasan Hasil Uji Pengaruh Mediasi Persamaan I

\begin{tabular}{|c|c|c|c|c|c|c|c|}
\hline \multirow[t]{2}{*}{ Model } & \multicolumn{2}{|c|}{ Unstandardized } & \multicolumn{2}{|c|}{ Harga $t$} & \multirow[t]{2}{*}{ Sig. } & \multicolumn{2}{|c|}{ Harga $r$ dan $r^{2}$} \\
\hline & B & Std. Error & t hitung & $\mathrm{t}$ tabel & & $\mathrm{R}$ & $\begin{array}{c}\mathrm{R} \\
\text { Square }\end{array}$ \\
\hline (Constanta) & $-0,157$ & 0,070 & $-2,240$ & \multirow[t]{2}{*}{2,2281} & 0,028 & \multirow[t]{2}{*}{0,272} & \multirow[t]{2}{*}{0,074} \\
\hline DER & $-0,157$ & 0,067 & $-2,327$ & & 0,023 & & \\
\hline
\end{tabular}

Dependent Variable : LnAC

Sumber : Output SPSS

Berdasarkan tabel 10 diketahui nilai unstandardized beta DER sebesar -0,157 merupakan nilai path atau jalur p2 dan signifikan pada 0,023 yang berarti leverage berpengaruh negatif terhadap Agency cost.

\section{Persamaan II}

$\operatorname{LnPBV}=\mathbf{a}+\mathbf{b D E R}+\mathrm{cLnAc}+\mathbf{e}_{2}$

Tabel 11. Ringkasan Hasil Uji Pengaruh Mediasi Persamaan II

\begin{tabular}{|c|c|c|c|c|c|c|c|}
\hline \multirow{2}{*}{ Model } & \multicolumn{2}{|c|}{ Unstandardized } & \multicolumn{2}{c|}{ Harga $\mathrm{t}$} & \multirow{2}{*}{ Sig. } & \multicolumn{2}{c|}{ Harga r dan $\mathrm{r}^{2}$} \\
\cline { 2 - 4 } \cline { 3 - 4 } & $\mathrm{B}$ & Std. Error & $\mathrm{t}$ hitung & $\mathrm{t}$ tabel & & $\mathrm{R}$ & $\mathrm{R}$ Square \\
\hline (Constanta) & 0,686 & 0,231 & 2,966 & 2,2281 & 0,004 & 0,576 & 0,332 \\
\hline DER & 0,451 & 0,223 & 2,022 & & 0,047 & & \\
\hline LnAc & $-1,795$ & 0,386 & $-4,654$ & & 0,000 & & \\
\hline
\end{tabular}

Dependent Variable: LnPBV

Sumber : Output SPSS

Berdasarkan tabel 11 nampak nilai unstandardized beta DER sebesar 0,451 merupakan nilai jalur path $\mathrm{p} 1$ dengan signifikansi 0,047 yang berarti leverage (DER) berpengaruh positif signifikan terhadap nilai perusahaan (PBV). Selain itu, juga diperoleh nilai unstandardized beta Agency cost sebesar -1,795 merupakan nilai path p3 dengannilai signifikansi 0,000 yang berarti Agency cost berpengaruh negatif signifikan terhadap nilaiperusahaan.

Berikut ini adalah analisis jalur untuk menguji hubungan antara leverage terhadap nilai perusahaan dan apakah hubungan leverage ke nilai perusahaan dimediasi oleh agency costsebagaimana disajikan pada gambar 5 sebagai berikut :

\section{Gambar 5}

Path AnalysisLeverage (DER) ke Nilai Perusahaan melalui Agency Cost

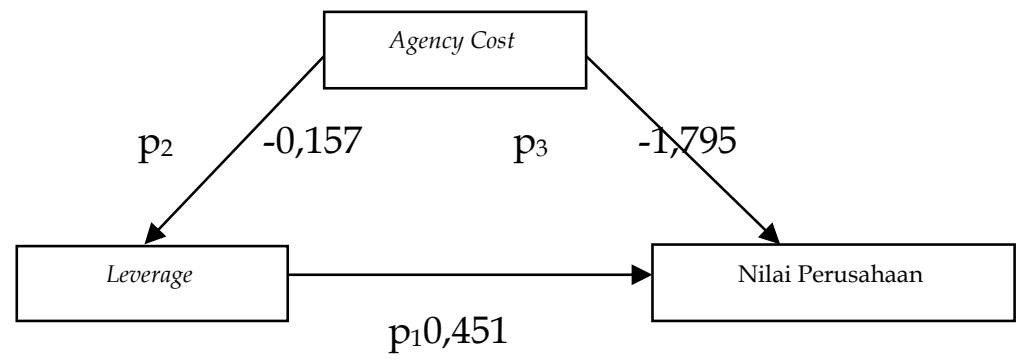

Tabel 12. Pengaruh Tidak Langsung dan Total

\begin{tabular}{|c|c|c|c|c|c|c|}
\hline $\begin{array}{c}\text { Variabel } \\
\text { Independen }\end{array}$ & $\begin{array}{c}\text { Variabel } \\
\text { Intervening }\end{array}$ & $\begin{array}{c}\text { Variabel } \\
\text { Dependen }\end{array}$ & $\begin{array}{c}\text { Pengaruh } \\
\text { Langsung }\end{array}$ & $\begin{array}{c}\text { Pengaruh } \\
\text { Tidak } \\
\text { Langsung }\end{array}$ & $\begin{array}{c}\text { Total } \\
\text { Effect }\end{array}$ & T Hitung \\
\hline Leverage & Agency Cost & $\begin{array}{c}\text { Nilai } \\
\text { Perusahaan }\end{array}$ & 0,451 & 0,281815 & 0,733 & 2,0551 \\
\hline
\end{tabular}

Sumber : Output SPSS 
Oleh karena nilai $\mathrm{t}$ hitung $(2,0551)$ lebih kecil dari nilai $\mathrm{t}$ tabel dengan tingkat signifikansi $5 \%$ yaitu sebesar 2,2281 maka dapat disimpulkan bahwa koefisien mediasi 0,281815 tidak signifikan yang berarti bahwa Agency cost tidak dapat memediasi antara leverage terhadap nilai perusahaan. Sehingga, hipotesis $6 \mathrm{~b}$ yang menyatakan leverage mempunyai pengaruh signifikan terhadap nilai perusahaan dengan Agency cost sebagai variabel intervening tidak terbukti.

\section{Kesimpulan}

Berdasarkan hasil analisis data dan pengujian hipotesis, maka kesimpulan dari penelitian ini adalah:

1. Kebijakan Dividen (DPS) berpengaruh negatif dan signifikan terhadap Agency cost.

2. Leverage (DER) berpengaruh negatif dan signifikan terhadap agency cost.

3. Kebijakan Dividen berpengaruh positif dan signifikan terhadap nilai perusahaan (PBV).

4. Leverage berpengaruh positif dan signifikan terhadap nilai perusahaan.

5. Agency cost berpengaruh negatif dan signifikan terhadap nilai perusahaan.

6. Agency cost mampu memediasi kebijakan dividen terhadap nilai perusahaan. Namun, Agency cost tidak mampu memediasi leverage terhadap nilai perusahaan.

\section{Daftar Pustaka}

Ambarwati, Indah \& Stephanus.2014. Struktur Kepemilikan, Kebijakan Dividen, \& Leverage Sebagai Determinan Atas Nilai Perusahaan.Jurnal Akuntansi Multiparadigma, Vol. 5, No. 5: 1-13.

Arifin, Z. 2007. Teori Keuangan E Pasar Modal.Yogyakarta : Ekonisia.

Brigham, Eugene. F.,\& Houston. 2006. Dasar-dasar Manajemen Keuangan. Buku 2.Jakarta : Salemba Empat.

Dwiaji, Y.C. 2011.Analisis Pengaruh Profitabilitas terhadap Keputusan Keuangan dan Dampaknya pada Nilai Perusahaan Industri-Industri yang Terdaftar di PT. Bursa Efek Indonesia (BEI) Tahun 2004-2009.(Tesis dipublikasikan, Universitas Brawijaya).

Ghozali, Imam. 2013. Analisis Multivariate dengan program IBM SPSS 21. Semarang:BP Undip.

Haryanti. 2011. Pengaruh Agency Cost terhadap Nilai Perusahaan dengan Kebijakan Dividen dan Struktur Modal sebagai Variabel Intervening.

Hermuningsih, S. 2013. Pengaruh Profitabilitas, Growth Opportunity, Struktur Modal terhadap Nilai Perusahaan Pada Perusahaan Publik di Indonesia.Journal Bank Indonesia, Vol. 16, No. 2: 1-22.

Hertiana, E.Y. 2016.Pengaruh Leverage dan Agency Cost terhadap Nilai Perusahaan pada Perusahaan Property dan Real Estate yang Terdaftar di Bursa Efek Indonesia Periode 2011-2015. (Tesis dipublikasikan, Universitas Widyatama).

Husnan, Suad. 2008. Manajemen Keuangan. Yogyakarta : BPFE UGM.

Jensen, Michael C, \&Meckling, William H. 1976.Theory of the Firm: Managerial Behavior, Agency Cost and Ownership Structure. Journal of Financial Economics, Vol. 3, No. 4;pp. 305-360. 
Lisnandy, B.Z. 2016.Pengaruh Kebijakan Dividen, Kebijakan Hutang, dan Profitabilitas terhadap Nilai Perusahaan Sektor Pertanian yang Terdaftar di Bursa Efek Indonesia (BEI) Periode 2010-2014.(Tesis dipublikasikan, Universitas Widyatama).

Munawir, S. 2010. AnalisaLaporan Keuangan. Yogyakarta: Liberty.

Muttaqien, A.R. 2010. Pengaruh Kebijakan Dividen, Kebijakan Leverage dan Kepemilikan Manajerial Terhadap Agency Cost pada Sektor Telekomunikasi Periode 20032008.(Skripsi dipublikasikan, Universitas Widyatama).

Pamungkas, S.A. 2016. Pengaruh Kebijakan Dividen dan Kebijakan Leverage terhadap Agency Cost pada Perusahaan yang Terdaftar di Jakarta Islamic Index Periode 20112014.(Tesis dipublikasikan, Universitas Widyatama).

Putra, Widana. A.A.G.P, Ni Made Dwi Ratnadi. 2004. Pengaruh Kebijakan Dividen dan Kepemilikan Manajerial Terhaap Kos Keagenan.Jurnal Jurusan Akuntansi Fakultas Ekonomi, Universitas Udayana.

Putri, I.S.W. 2015.Pengaruh Leverage dan Kebijakan Dividen terhadap Agency Cost (Studi pada Perusahaan Sub Sektor Otomotif Terdaftar di Bursa Efek Indonesia Periode 2009-2013).(Tesis dipublikasikan, Universitas Widyatama).

Riduwan dan Kuncoro, E.A. 2014.Cara Menggunakan dan Memaknai Path Analysis.Bandung: Alfabeta.

Rustendi, T. Jimmi, F. 2008. Pengaruh Hutang dan Kepemilikan Manajerial Terhadap Nilai Perusahaan pada Perusahaan Manufaktur (Survey Pada Perusahaan Manufaktur yang tercatat di Bursa Efek Indonesia).Jurnal Akuntansi Fakultas Ekonomi, Universitas Siliwangi, Vol. 3, No. 1: 1-12.

Sugiyono. 2013. Metode Penelitian Kuantitatif, Kualitatif dan RED. Bandung : Alfabeta.

Sukirni, D. 2012. Kepemilikan Manajerial, Kepemilikan Institusional, Kebijakan Deviden dan Kebijakan Hutang Analisis terhadap Nilai Perusahaan. Accounting Analysis Journal, Vol. 1, No. 2:15-25.

Somantri, D.F.R. dan Sri, Edi. 2016. Pengaruh Agency Cost dan Struktur Modal terhadap Nilai Perusahaan (Studi pada Perusahaan Perbankan yang Terdaftar di Bursa Efek Indonesia Tahun 2011-2014). Jurnal Sivitas Akademika Unisba, Vol.2, No. 1: 1-9.

Tansil, J. 2015. Pengaruh Struktur Modal, Agency Cost, dan Kebijakan Dividen terhadap Nilai Perusahaan Manufaktur di Bursa Efek Indonesia.(Tesis dipublikasikan, Universitas Widya Mandala).

Triwahyuni, F. 2016. Analisis Faktor-faktor yang Mempengaruhi Agency Cost dan Pengaruhnya terhadap Nilai Perusahaan pada Industri Pertambangan yang Terdaftar di Bursa Efek Indonesia (BEI) Periode 2010-2014.(Tesis dipublikasikan, Universitas Widyatama). 
Wijaya, Lihan Rini, Puspo, Bandi dan Anas, Wibawa. 2010. Pengaruh Keputusan Investasi, Keputusan Pendanaan, dan Kebijakan Dividen terhadap Nilai Perusahaan. Simposium Nasional Akuntansi XIII Purwokerto, Vol. 13: 1-21. (Universitas Jenderal Soedirman, Purwokerto).

$\underline{\text { www.idx.co.id }}$

$\underline{\text { www.sahamok.com }}$ 